\title{
DIFUSI INOVASI DALAM PROGRAM PEMBELAJARAN JARAK JAUH DI YAYASAN TRAMPIL INDONESIA
}

\author{
Monika Teguh* \\ Universitas Ciputra, Surabaya, INDONESIA \\ *Penulis korespondensi, email: monika.teguh@gmail.com
}

\begin{abstract}
ABSTRAK
Penelitian ini bertujuan untuk mendeskripsikan difusi inovasi yang dilakukan oleh Yayasan TRAMPIL Indonesia dalam pelaksanaan Program Learn and Teach. Program ini diadakan untuk memfasilitasi guru-guru SD dan PAUD di berbagai tempat di Indonesia yang kesulitan mengakses pendidikan tinggi. Dalam program ini digunakan metode kombinasi antara pertemuan tatap muka, web conference dan learning management system agar hasil belajar dapat maksimal walaupun para peserta program berada pada lokasi yang berjauhan dan memiliki latar belakang budaya yang berbeda-beda. Penelitian ini merupakan penelitian kualitatif deskriptif, dengan metode pengumpulan data melalui pengamatan dan wawancara. Difusi Inovasi disini terlihat dari inovasi dalam penggunaan teknologi informasi dan komunikasi dalam pembelajaran jarak jauh, saluran komunikasi melalui komunikasi interpersonal dan komunikasi kelompok, jangka waktu difusi selama tiga tahun, dan penetrasi melalui sistem sosial seperti sekolah dan institusi keagamaan. Kekhususan dari difusi inovasi yang dilaksanakan oleh Yayasan TRAMPIL Indonesia adalah keberhasilannya untuk melakukan penetrasi teknologi baru pada wilayah-wilayah yang masih belum terjangkau pembangunan. Teknologi yang dibawa oleh TRAMPIL adalah teknologi mutakhir dan bahkan belum banyak digunakan di perkotaan. Namun dengan pendekatan melalui saluran komunikasi dan sistem sosial yang tepat, maka inovasi ini dapat diterima dengan baik dalam waktu yang relatif singkat.
\end{abstract}

Kata kunci: Difusi inovasi, teknologi informasi dan komunikasi, pembelajaran jarak jauh.

\begin{abstract}
This research aimed to describe the difussion of innovations conducted by TRAMPIL Indonesia Foundation in their "Learn and Teach" Program. The program was held to facilitate primary and early childhood education teachers in various places in Indonesia who have difficulty accessing higher education.This program used a combination method in the form of face to face meeting, web conferencing, and learning management system in order to maximize learning outcomes, even though the participants of the program were at remote locations and had different cultural backgrounds. This research was a descriptive qualitative research, using observation and interview as the method of collecting data. The diffusion of innovations here was seen from the innovation of using information and communication technology for long distance learning, the communication channel through interpersonal and group communication, the time of difusion as long as three years, an the penetration through social system such as school and religion institusi. The superiority of this diffusion of innovations was its success for the penetration of new technologies in the underdeveloped regions. The technology brought by TRAMPIL was a cutting-edge technology and even had not been widely used in urban areas. But with a good approach via proper communication channel and social system, this innovation could be received in a relatively short time.
\end{abstract}

Keywords: Diffusion of innovations, information and communication technology, long distance learning.

\section{PENDAHULUAN}

Indonesia merupakan sebuah negara kepulauan besar yang terletak pada koordinat enam derajat lintang utara sampai sebelas derajat lintang selatan, dan dari sembilah puluh lima derajat bujur timur hingga seratus empat puluh satu derajat bujur timur (Hartono, 2007). Di dalamnya terdapat 13.487 pulau yang sudah teridentifikasi dan letaknya tersebar di dalam koordinat tersebut (Paonganan, Zulkipli, \& Agustina, 2012). Dengan kondisi geografis tersebut, maka masyarakat Indonesia tinggal dalam pulau-pulau yang dipisahkan oleh laut. Untuk menghubungkan satu pulau dengan pulau lain dibutuhkan usaha yang tidak sedikit, sehingga pembangunan terhadap masyarakat di pulau-pulau yang jauh dari ibu kota merupakan tantangan tersendiri bagi bangsa Indonesia. Hal ini berpengaruh juga kepada dunia pendidikan di Indonesia. Sumardi (2005) dalam bukunya Melawan Stigma Melalui Pendidikan Alternatif menyebutkan bahwa telah terjadi ketimpangan pemerataan pendidikan Indonesia karena masalah geografis, terutama antara wilayah perkotaan dan pedesaan, serta antara Kawasan Timur Indonesia (KTI) dan Kawasan Barat 
Indonesia (KBI). Wilayah perkotaan serta KBI umumnya memperoleh pengembangan pendidikan yang lebih baik daripada wilayah pedesaan dan KTI. Hal ini menjadi masalah karena pengembangan pendidikan akan berpengaruh pada pengembangan sumber daya manusia yang pada akhirnya akan menentukan kesejahteraan masyarakat di suatu wilayah. Maka dari itu harus dicari sebuah solusi alternatif untuk membantu meningkatkan pendidikan di wilayah-wilayah yang sulit dijangkau tersebut.

Berawal dari permasalahan ini, Yayasan TRAMPIL Indonesia, sebuah Yayasan yang bergerak dibidang pendidikan melalui e-learning mencoba menjalankan suatu alternatif solusi. Yayasan TRAMPIL Indonesia digagas pada saat penyelenggaraan Asia Pacific Transformation Conference (APTC) di Jakarta pada Oktober 2010. Dalam konferensi yang membahas tentang solusi untuk mentransformasi Indonesia tersebut, dirumuskan ide untuk melaksanakan pembelajaran jarak jauh dengan menggunakan Teknologi Informasi dan Komunikasi (TIK). Solusi tersebut dirancang untuk mengakomodasi kondisi geografis Indonesia yang menyebabkan pemerataan pendidikan menjadi mahal dan berbenturan dengan banyak kendala teknis di lapangan. Sebagai contoh, jika ingin mengirimkan tenaga pengajar di daerah yang kekurangan guru, maka akan ada kendala untuk membiayai transportasi, akomodasi dan kehidupan guru tersebut yang tentu saja tidak murah. Belum lagi guru tersebut bisa jadi kesulitan menyesuaikan diri dengan budaya di tempat baru dan tidak mampu bertahan disana. Maka dari itu mendidik guru lokal akan lebih efektif dan efisien daripada mendatangkan guru dari luar daerah. Namun kendala lain akan muncul jika di wilayah tersebut tidak ada institusi pendidikan bagi guru. Mengirimkan guru dari daerah untuk menempuh pendidikan di wilayah lain juga akan memunculkan kendala yang serupa dengan mendatangkan guru tadi. Maka dari itu, salah satu solusi terbaik adalah mendidik guru lokal di tempat tinggalnya sendiri, menggunakan teknologi pembelajaran jarak jauh yang secara teknis lebih memungkinkan untuk dilaksanakan daripada membangun institusi pendidikan baru di wilayah tersebut (Andriono, 2015). Dari pemikiran itulah akhirnya Yayasan TRAMPIL Indonesia didirikan dengan tujuan utama untuk mentransformasi bangsa Indonesia melalui pendidikan menggunakan pembelajaran jarak jauh.

Meskipun ide telah tercetus, namun pada pelaksanaannya untuk membangun suatu sistem pelaksanaan program pembelajaran jarak jauh tidaklah mudah. Terdapat berbagai kendala yang harus dihadapi seperti meyakinkan masyarakat mengenai cara pembelajaran yang masih baru, mengatasi ketakutan mereka akan keterbatasan fasilitas yang ada, maupun menjalin hubungan dengan berbagai pihak terkait. Menghadapi hal ini, Yayasan TRAMPIL Indonesia telah melakukan difusi inovasi sejak tahun 2010 dan akhirnya pada tahun 2013 meluncurkan program pembelajaran jarak jauh pertama mereka yang disebut dengan Program Learn and Teach. Sampai saat ini program tersebut telah membantu lebih dari 1.000 orang guru di 17 kabupaten/kota yang tersebar di seluruh Indonesia. Melihat hal ini, peneliti ingin menjabarkan lebih jauh proses difusi inovasi yang dilakukan Yayasan TRAMPIL Indonesia sehingga pembelajaran jarak jauh yang merupakan sesuatu yang masih sangat baru dapat diterima dengan baik oleh masyarakat Indonesia yang jauh dari perkotaan. Penelitian ini diharapkan dapat menjadi acuan bagi institusi-intitusi lain yang juga ingin melakukan program pembelajaran jarak jauh maupun menolong masyarakat di area-area bagian luar Indonesia.

\section{TINJAUAN PUSTAKA}

\subsection{Difusi Inovasi}

Rogers (2003) menjelaskan difusi Inovasi merupakan sebuah proses dimana gagasan baru dikomunikasikan kepada masyarakat. Hal menjadi kekhasan dari difusi inovasi adalah terdapat kebaruan dalam sebuah pesan yang disampaikan, sehingga tersebut menimbulkan ketidakpastian dalam benak komunikan. Ketidakpastian ini menyebabkan pesan tidak mudah diterima oleh komunikan, karena gagasan tersebut masih perlu dicoba dan manfaatnya masih belum dapat dibayangkan. Maka dari itu diperlukan konstruksi sosial untuk dapat menjalankan dan mengembangkan gagasan tersebut. Terdapat empat unsur dalam difusi inovasi yaitu:

1. Inovasi

Inovasi tentu saja merupakan unsur utama dalam proses difusi inovasi. Inovasi inilah yang menyebabkan perlunya dilakukan difusi inovasi. Inovasi dapat diartikan sebagai sebuah ide, praktik, maupun objek yang masih baru bagi individu maupun masyarakat. Terdapat lima karakteristik inovasi yang mempengaruhi keputusan individu atau masyarakat untuk menerima atau menolak keputusan tersebut yaitu:

a. Keunggulan Relatif (Relative Advantage)

Apa yang dimaksud dengan keunggulan relatif adalah kelebihan sebuah inovasi dibandingkan dengan kondisi tanpa adanya inovasi tersebut. 
Jika inovasi tersebut memiliki keunggulan yang besar, maka masyarakat akan lebih mudah menerima inovasi tersebut. Keunggulan ini dapat dilihat dari berbagai segi seperti nilai ekonomis, efisiensi, prestise sosial, Kenyamanan, kepuasan, dan lain-lain.

b. Kompabilitas (Compability)

Yang dimaksud dengan kompabilitas adalah kesesuaian antara inovasi dengan nilai-nilai yang berlaku, bidang pengalaman penerima, dan kebutuhannya. Jika inovasi tersebut bertentangan dengan nilai-nilai yang berlaku, tidak sejalan dengan pengalaman dari penerima, maupun tidak sesuai kebutuhan maka inovasi tersebut akan sulit untuk diterima.

c. Kerumitan (Complexity)

Suatu inovasi memiliki kerumitan tertentu untuk dapt dipahami dan digunakan oleh masyarakat. Semakin rumit dan sulit untuk diaplikasikan, maka inovasi tersebut juga akan lebih sulit untuk diterima.

d. Kemampuan untuk diujicoba (Trialablity) Agar sebuah inovasi lebih mudah diterima maka diperlukan demonstrasi yang dapat dilihat atau dirasakan masyarakat. Jika uji coba dapat dirasakan langsung, maka inovasi tersebut akan lebih mudah diterima dibandingkan jika hanya diperlihatkan.

e. Kemampuan untuk diamati (Observablity) Hasil dari inovasi juga akan mempengaruhi tingkat penerimaannya. Maka dari itu semakin mudah hasil atau dampak dari inovasi tersebut dilihat oleh orang lain, semakin mudah pula inovasi tersebut diterima.

2. Saluran Komunikasi

Setelah adanya suatu inovasi, maka hal berikutnya yang harus dilakukan adalah mengomunikasikannya. Komunikasi disini bertujuan untuk mencapai mutual understanding antara pembawa inovasi dengan penerima inovasi tersebut. Agar pesan yang dibawa oleh komunikator dapat tersampaikan dengan baik haruslah dipilih saluran komunikasi yang tepat. Dalam difusi inovasi umumnya terdapat beberapa saluran komunikasi yang dapat digunakan yaitu antar pribadi, media massa, saluran lokal, dan saluran kosmopolit.

Saluran antar pribadi merupakan saluran yang paling dasar yang dapat digunakan, yaitu dengan menyampaikan langsung dari individu kepada individu lainnya. Media massa juga merupakan salah satu saluran yang dianggap efektif terutama jika sasaran difusi inovasi adalah masyarakat dalam jumlah besar dan berada pda lokasi yang berjauhan. Namun media massa akan lebih rendah efektifitasnya jika digunakan untuk memberikan inovasi yang sulit diterima. Saluran lokal merupakan salah satu saluran yang lebih efektif untuk menyosialisasikan inovasi yang lebih rumit karena pesan dimasukkan melalui sistem sosial yang ada. Saluran ini membutuhkan usaha untuk mengenali sistem sosial dan menyesuaikan pesan dengan kondisi sistem sosial tersebut. Sedangkan saluran kosmopolit adalah saluran yang berada diluar sistem sosial yang ada. Saluran ini lebih sesuai untuk membentuk awareness awal karena lebih bersifat memberikan informasi dan lebih sedikit persuasi yang diberikan.

3. Waktu

Waktu juga merupakan sesuatu yang sangat krusial dalam difusi inovasi. Dimensi waktu dapat dilihat dari beberapa sisi dalam mempengaruhi difusi inovasi. Yang pertama adalah dari segi penerimanya. Umumnya usia akan mempengaruhi penerimaan suatu inovasi. Seseorang yang lebih tua akan cenderung lebih lambat menerima inovasi dibandingkan dengan seseorang yang lebih muda, sehingga mereka membutuhkan waktu yang lebih panjang untuk proses difusi inovasi. Selain penerima, tahapan penerimaan juga berada dalam dimensi waktu. Inovasi umumnya dimasukkan dalam beberapa tahapan yaitu penyaluran pengetahuan, pembentukan sikap, pengambilan keputusan penerimaan terhadap inovasi, pelaksanaan inovasi, dan konfirmasi dari keputusan. Dalam tiap tahapan tersebut komunikator harus mampu melihat dan mengatur waktu yang tepat agar tiap tahapan dapat berjalan dengan baik.

4. Sistem Sosial

Sistem sosial merupakan unit-unit yang saling berhubungan dan tergabung dalam usaha untuk memecahkan suatu masalah dan mencapai tujuan tertentu. Sistem sosial ini dapat berupa organisasi, sub sistem dari sebuah organisasi, maupun kelompok masyarakat. Proses difusi dalam sistem sosial sangat dipengaruhi oleh beberapa hal antara lain norma sosial yang berlaku, struktur sosial dari sistem tersebut, peranan pemimpin dan agen perubahan, tipe pengambilan keputusan dalam sistem sosial, serta cara mereka menghadapi konsekuensi.

\subsection{Pembelajaran Jarak Jauh (E-Learning)}

Pembelajaran jarak jauh atau dalam kasus ini kita kenal juga dengan e-learning merupakan sebuah metode pembelajaran baru yang menggunakan teknologi informasi dan komunikasi sebagai alat 
utamanya untuk menyampaikan materi dan strategi pembelajaran. Disini ada beberapa perbedaan utama dari kegiatan belajar mengajar konvensional yaitu tidak lagi terbatasi oleh ruangan, waktu pembelajaran jauh lebih fleksibel, lebih banyak berbasis online daripada menggunakan kertas, mengganti fasilitas fisik dengan fasilitas bebasis jaringan, serta pembaruan informasi yang lebih cepat (Rosenberg, 2001). Terdapat beberapa bentuk dari e-learning dan masih terus berkembang sampai saat ini, diantaranya adalah (Horton, 2011):

- Standalone Courses: merupakan pembelajaran yang dilakukan oleh perseorangan, dimana individu tersebut melakukan pembelajaran mandiri dengan sumber-sumber yang berasal dari internet. Tidak ada keterlibatan instruktur maupun teman belajar dalam bentuk ini.

- Virtual-Classroom Courses: Pembelajaran online yang dirancang seperti pembelajaran dalam kelas. Disini dapat terjadi pertemuan rutin yang disepakati bersama antar peserta pembelajaran.

- Learning in games and simulations: Pembelajara melalui eksplorasi pribadi peserta didik dalam permainan atau simulasi. Disini diberikan petunjuk-petunjuk agar peserta didik bisa memahami tahapan eksplorasi yang harus mereka lakukan.

- Embedded E-Learning: Sistem pembelajaran tergabung dalam suatu sistem, seperti program komputer, diagnostic procedure, atau bantuan online.

- Blended Learning: Pembelajaran yang menggabungkan berbagai metode untuk mencapai tujuan tertentu atau mengakomodasi situasi tertentu. Bisa jadi menggabungkan metode konvensional dengan e-learning atau menggabungkan berbagai bentuk e-learning yang ada.

- Mobile Learning: Pembelajaran yang dapat diakses dari smart phones atau gadget lain yang compatible.

- Knowledge Management: Penggunaan e-learning secara lebih luas, dimana sasarannya adalah populasi besar bukan individu.

Meskipun metode pembelajaran ini memiliki banyak keunggulan dibandingkan dengan metode pembelajaran konvensional, tetap harus diperhatikan bahwa inti utama dari pembelajaran terletak pada materi pembelajaran dan strategi instruksional untuk memahami materi pembelajaran tersebut. Teknologi yang ada hanya merupakan kendaraan agar materi dan strategi pembelajaran dapat diterima oleh para murid. Maka dari itu penting bagi lembaga pelaksana e-learning untuk dapat memikirkan berbagai aktivitas pembelajaran yang dapat membuat materi tertangkap baik oleh peserta didik. Disini keunggulan dari teknologi informasi dan komunikasi tersebut dapat dimanfaatkan sebaik-baiknya karena banyak hal yang bisa lebih dieksplorasi dibandingkan pada pembelajaran konvensional (Anderson, 2008).

\section{METODE PENELITIAN}

Dalam penelitian ini digunakan metode penelitian kualitatif. Penelitian kualitatif bertujuan untuk memberikan gambaran dan pemahaman mengenai realitas atau fenomena komunikasi yang sedang terjadi. Maka dari itu penelitian ini tidak dilakukan dengan menunjukkan bukti-bukti angka, logika matematis, maupun teknik statistik. Disini lebih banyak diambil data dari hal-hal yang bersifat diskursif seperti transkrip wawancara, hasil observasi, catatan lapangan, maupun gambar-gambar kejadian (Pawito, 2007). Metode ini memungkin peneliti menggali secara mendalam detil-detil kecil yang ada dalam setiap kejadian, seperti memunculkan lorong-lorong dari sebuah peta. Metode ini juga meneliti hal-hal kecil yang muncul karena percaya bahwa kebenaran besar bersumber dari hal-hal kecil tersebut (Daymon \& Holloway, 2002).

Secara khusus dalam penelitian ini akan menggunakan jenis metode studi kasus. Menurut Creswell studi kasus bertujuan untuk mendalami suatu kasus yang memiliki signifikansi tertentu dengan cara mengumpulkan berbagai sumber informasi. Disini akan dilakukan ekplorasi dari sistem-sistem terkait yang ada dalam kasus tersebut. Patton menambahkan bahwa studi kasus berusaha untuk memahami kompleksitas suatu kasus tunggal dalam konteks, waktu dan situasi tertentu (Raco, 2010). Maka dari itu tidak dapat dilakukan generalisasi dalam jenis metode ini.

\section{HASIL DAN PEMBAHASAN}

Pembelajaran jarak jauh menggunakan teknologi informasi dan komunikasi merupakan sebuah hal baru bagi masyarakat Indonesia. Dibutuhkannya infrastruktur serta perangkat teknologi yang memadai menjadi salah satu penyebab jenis pembelajaran ini masih belum populer di masyarakat. Umumnya yang sudah mulai mengenal jenis pembelajaran ini adalah masyarakat yang berada di wilayah perkotaan, dimana mereka sudah lebih mudah memperoleh fasilitas-fasilitas yang dibutuhkan untuk menjalankan bentuk pembelajaran ini. Jika ditelaah lebih jauh, sesungguhnya wilayah-wilayah terpencil di Indonesia justru yang membutuhkan bentuk pembelajaran ini. 
Hal ini disebabkan jika dihitung dari segi biaya, menyelenggarakan e-learning jauh lebih murah jika dibandingkan mendirikan institusi pendidikan konvensional. Selain itu waktu yang dibutuhkan juga lebih singkat.

Namun yang menjadi masalah adalah penerimaan masyarakat terhadap inovasi baru ini. Menurut pengalaman dalam pelaksanaan program Learn and Teach yang diselenggarakan oleh Yayasan TRAMPIL Indonesia, masyarakat masih mengalami ketakutan akan hal baru ini. Ada beberapa ketakutan yang mereka alami. Yang pertama adalah penyediaan perangkat teknologi agar program dapat berjalan. Memang jika dihitung diawal, penyediaan perangkat biayanya cukup besar bagi masyarakat daerah pedesaan, namun sesungguhnya jika diperhitungkan dalam jangka waktu panjang dan dari segi manfaat bentuk pembelajaran ini jauh lebih efisien. Namun melihat angka untuk penyediaan barang diawal membuat mereka takut. Hal lain yang menjadi ketakutan mereka adalah keabsahan dari hasil pembelajaran jarak jauh. Mereka khawatir bahwa jenis pembelajaran ini tidak diakui oleh Pemerintah sehingga hasil usaha mereka untuk belajar sekian lamanya menjadi sia-sia. Hal lain yang menjadi ketakutan mereka adalah kesinambungan dari program ini. Dikhawatirkan program ini hanyalah program percobaan yang tidak dapat berlangsung lama dan bersifat sporadis saja. Ketakutan-ketakutan inilah yang harus dijawab oleh Yayasan TRAMPIL Indonesia.

Berawal dari permasalahan tersebut, Yayasan TRAMPIL Indonesia melakukan pendekatan selama tiga tahun. Program yang diinisiasi pada tahun 2010 tersebut mulai disebarkan terutama di wilayahwilayah timur Indonesia yang paling membutuhkan bantuan, serta beberapa wilayah di pulau Jawa. Akhirnya perlahan-lahan program ini dapat diterima dan pada tahun 2013 program ini dijalankan. Pendekatan yang dilakukan oleh Yayasan TRAMPIL Indonesia ini sesungguhnya merupakan suatu proses difusi inovasi yang dapat dijabarkan sebagai berikut:

\subsection{Inovasi}

Inovasi yang dilakukan oleh Yayasan TRAMPIL Indonesia disini adalah program pembelajaran jarak jauh. Secara khusus program ini dinamakan Program Learn and Teach yang bertujuan untuk membantu guru-guru Pendidikan Anak Usia Dini (PAUD) dan Sekolah Dasar yang belum memiliki ijazah S1.
Guru-guru tersebut perlu dibantu karena adanya Undang-Undang no. 14 tahun 2005 yang mensyaratkan bahwa tenaga pendidik harus memiliki ijazah S1 sesuai dengan bidang kerjanya agar dapat terus mengajar. Hal ini akan diberlakukan secara efektif mulai tahun 2020. Implikasinya, guru-guru yang tidak memiliki ijazah S1 tidak lagi diperkenankan mengajar dan sekolah yang tetap nekat mempekerjakan guruguru tersebut juga akan dikenai sanksi. Tujuan dari Undang-Undang ini sesungguhnya adalah untuk meningkatkan mutu pendidikan, namun kenyataannya banyak sekali wilayah di Indonesia yang mengalami kesulitan dengan diberlakukannya UU ini. Perguruan Tinggi yang jumlahnya terbatas dan umumnya berada di kota atau kabupaten besar menjadi kendala utama yang mereka hadapi. Berawal dari permasalahan inilah sebuah inovasi untuk membantu guru-guru agar bisa memperoleh pendidikan jenjang S1 walau mereka berada di wilayah terpencil dicetuskan oleh Yayasan TRAMPIL Indonesia.

Program ini dapat menjawab permasalahan tersebut karena tidak diperlukan pembangunan gedung baru maupun sumber daya manusia dalam jumlah banyak seperti yang dibutuhkan oleh institusi perguruan tinggi pada umumnya. Cukup dengan memiliki minimal satu ruangan memadai berkapasitas 50 orang dan memiliki daya listrik sekitar 2200 watt, 2 orang fasilitator untuk menjalankan program, serta satu buah institusi resmi yang bersedia menjadi mitra penaung program di daerah maka suatu wilayah sudah dapat menjadi pelaku dari program ini. Sisanya kebutuhan peralatan, tenaga pengajar, maupun perizinan lainnya akan didukung oleh Yayasan TRAMPIL Indonesia. Maka dari itu sangat memungkinkan bagi orangorang di wilayah terpencil sekalipun untuk dapat terlibat dalam program ini. Tujuan akhir dari program ini adalah memberikan ijazah S1 Pendidikan Guru PAUD (PGPAUD) atau S1 Pendidikan Guru SD (PGSD) kepada guru yang belum memilikinya. Program ini dirancang untuk pembelajaran selama sembilan semester bagi S1 PGPAUD atau sepuluh semester bagi PGSD. Program ini bekerjasama dengan Universitas Terbuka yang akan mengeluarkan ijazah resmi yang diakui pemerintah. Sedangkan bentuk pembelajarannya menggunakan metode blended learning dimana digabungkan antara pertemuan tatap muka tradisional dengan e-learning melalui web conference dan learning management system. Secara utuh, mekanisme program dapat dilihat pada Gambar 1. 


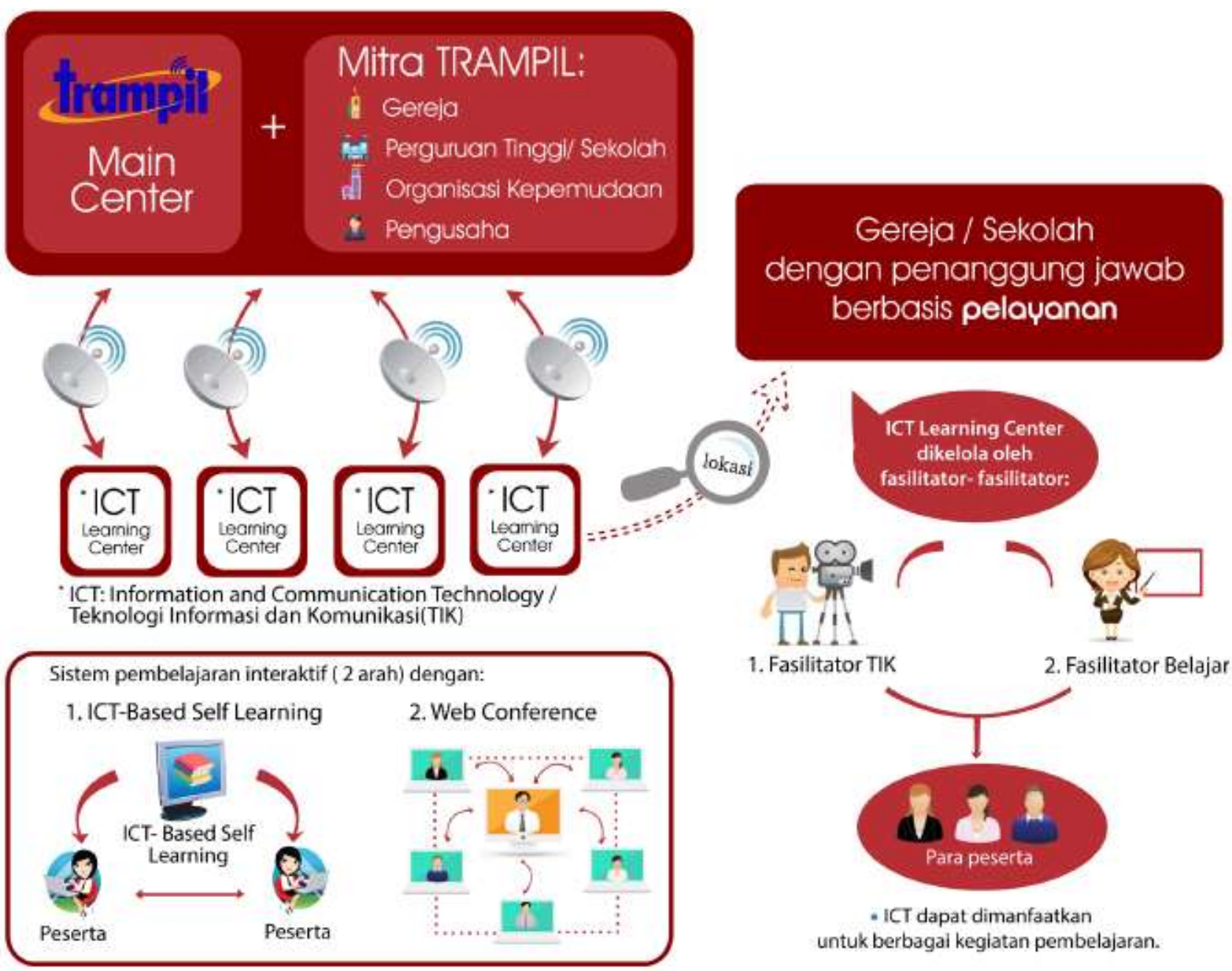

Gambar 1. Mekanisme Program Learn and Teach

Pada awalnya Yayasan TRAMPIL Indonesia mendirikan main center atau pusat pembelajaran yang berlokasi di jalan Keputran no. 67 Surabaya. Main center ini berfungsi sebagai host bagi keseluruhan program belajar. Disini dikembangkan sistem belajar mengajar, teknologi informasi dan komunikasi termasuk di dalamnya perangkat lunak untuk pembelajaran, bahan ajar, sampai dengan hal-hal administratif yang diperlukan. Kemudian Yayasan TRAMPIL Indonesia mulai mendatangi berbagai lembaga-lembaga di daerah yang membutuhkan. Secara khusus yang dibidik oleh Yayasan TRAMPIL Indonesia adalah lembaga agama seperti gereja, dan juga sekolah. Lembaga ini dipilih karena lembagalembaga tersebut umumnya banyak berhubungan dengan guru-guru di daerah sehingga akan memudahkan koordinasi. Setelah menemukan mitra kerja yang sesuai dengan kebutuhan yang ada, maka Yayasan TRAMPIL Indonesia akan menandatangani perjanjian kerjasama dengan lembaga tersebut, dimana lembaga tersebut akan menjadi penaung dari sebuah ICT Learning Center di wilayahnya. Lembaga tersebut kemudian harus menugaskan satu orang fasili- tator yang menangani keperluan teknologi informasi dan komunikasi (TIK) serta satu orang fasilitator untuk menangani kebutuhan akademis. Kedua fasilitator tersebut kemudian dilatih oleh Yayasan TRAMPIL Indonesia, baik dengan cara didatangkan ke main center, pertemuan berkala melalui web conference, maupun dilatih dilokasi ICT Learning Center. Fasilitator-fasilitator inilah yang menjadi perpanjangan tangan dari Yayasan TRAMPIL Indonesia untuk dapat mengelola proses belajar mengajar dan kebutuhan peserta didik di ICT Learning Center.

\subsection{Saluran Komunikasi}

Dalam pendekatannya, saluran pertama yang digunakan oleh Yayasan TRAMPIL Indonesia adalah saluran komunikasi interpersonal. Ketua Yayasan, Wakil Ketua Yayasan dan Kepala Program mendatangi sendiri wilayah-wilayah yang hendak diajak bekerjasama. Mereka mulanya masuk dari referensi Majelis Pendidikan Kristen (MPK) di Indonesia yang merupakan salah satu lembaga yang turut mencetuskan inovasi e-learning ini. Gereja-gereja dan sekolah 
yang memiliki hubungan dengan MPK dihubungi melalui telepon terlebih dahulu mengenai adanya program ini. Karena adanya referensi dari MPK, maka Yayasan TRAMPIL Indonesia umumnya dapat diterima dengan baik oleh lembaga-lembaga tujuan. Setidaknya Yayasan TRAMPIL dapat mereka percaya sebagai sebuah lembaga yang nyata dan tidak berusaha membohongi mereka.

Selanjutnya setelah Yayasan diterima baik, maka selanjutnya salah satu perwakilan dari TRAMPIL datang langsung ke lokasi calon mitra untuk berkomunikasi secara tatap muka dengan mereka. Komunikator yang dikirimkan selalu adalah para pejabat utama TRAMPIL. Hal ini dilakukan karena Yayasan TRAMPIL ingin menunjukkan niat tulus dan kesungguhan mereka dalam pelaksanaan program ini. Karena pendekatan melalui komunikasi interpersonal ini, maka mereka dengan mudah dapat diterima. Para calon mitra merasa lebih dihormati dan mereka juga menjadi lebih terbuka. Pesan utama yang diusung saat pertemuan ini adalah urgensi dari program ini. Masih banyak calon mitra yang tidak mengetahui diberlakukannya UU no.14 tahun 2005 secara efektif pada tahun 2020. Maka dari itu program ini sangatlah penting untuk dapat dilaksanakan. Selain itu juga ditekankan bahwa Yayasan TRAMPIL Indonesia didukung oleh berbagai donatur mandiri sehingga pihak calon mitra tidak perlu khawatir mengenai pengadaan alat maupun sistem pembelajaran. Mereka hanya perlu berkomitmen untuk menjalankan program ini dan menyediakan ruangan beserta dua orang fasilitator. Komunikan yang dipilih umumnya adalah kepala sekolah, ketua yayasan pendidikan, atau gembala gereja yang dapat mengambil keputusan atau memberikan pengaruh pada kebijakan lembaga. Mereka dipilih karena mereka umumnya dekat dengan dunia pendidikan dan memiliki akses kepada guru-guru sehingga akan mampu memahami urgensi dari program ini. Umumnya setelah pertemuan tersebut, para calon mitra menyetujui pelaksanaan program ini di tempat mereka karena mereka dapat memahami bahwa program ini penting dan tidak terlalu membebani mereka.

\subsection{Waktu}

Dalam melakukan difusi inovasi, Yayasan TRAMPIL Indonesia mengambil momentum yang tepat. Momentum yang dipergunakan adalah pemberlakukan UU no.14 tahun 2005 yang menyebabkan program Learn and Teach menjadi penting untuk dapat segera dilaksanakan. Dengan pemahaman akan pemberlakuan UU tersebut, maka komunikan dalam hal ini adalah para calon mitra untuk pendirian ICT Learning Center umumnya mengambil keputusan dengan cukup cepat. Dalam kurun waktu tiga tahun pelaksaanaan difusi inovasi, Yayasan TRAMPIL berhasil mengajak 23 mitra dari 17 kabupaten/kota antara lain Sentani - Papua, Numfor - Papua, Makale - Tanah Toraja, Rantepao - Tanah Toraja, Pontianak - Kalimantan, Waingapu - Sumba Timur, Waibakul - Sumba Tengah, Waikabubak - Sumba Barat, Sobawawi - Sumba Barat, Kupang - Nusa Tenggara Timur, Soe - Nusa Tenggara Timur, Gilimanuk Bali, Surabaya, Malang, Lumajang, Magelang, dan Sragen.

\subsection{Sistem Sosial}

Salah satu kunci keberhasilan difusi inovasi dari Yayasan TRAMPIL Indonesia adalah melakukan penetrasi melalui sistem sosial yang tepat. Yayasan TRAMPIL masuk ke dalam lingkungan yang dekat dengan pendidikan dan memahami benar nasib para guru. Di beberapa wilayah Yayasan TRAMPIL langsung masuk melalui kepala sekolah atau Yayasan penyelenggara pendidikan. Intitusi tersebut tentu saja dengan mudah memahami urgensi dan manfaat dari inovasi baru ini. Selain itu mereka sendiri adalah orang-orang yang terdampak permasalahan yang membutuhkan inovasi ini sebagai jawaban. Maka dari itu pendekatan kepada institusi pendidikan menjadi lebih mudah. Selain institusi pendidikan, lembaga lain yang didekati oleh Yayasan TRAMPIL adalah lembaga keagamaan seperti gereja. Hal ini dilakukan karena dibeberapa wilayah tertentu, peran lembaga gereja sangat besar dalam masyarakat. Masyarakat memiliki kepercayaan tinggi kepada gereja, sehingga jika gereja yang merekomendasikan maka kecenderungan mereka untuk menerima suatu inovasi menjadi lebih besar. Maka dari itu disini dilakukan pendekatan juga melalui gereja.

Setelah masuk melalui institusi pendidikan maupun gereja, langkah berikutnya untuk melakukan difusi inovasi kepada target sasaran yaitu para guru menjadi jauh lebih mudah. Pimpinan mereka, baik dalam hal ini pemimpin yayasan pendidikan, kepala sekolah, maupun pemuka agama membantu memberikan pemahaman akan pentingnya program ini. Beberapa sekolah bahkan sudah mewajibkan gurunya untuk mengikuti program Learn and Teach karena bagaimanapun juga mereka akan membutuhkan program ini. Disamping itu peran fasilitator juga sangat besar. Fasilitator seringkali pergi kepada guru-guru yang ada di wilayahnya dan menyampaikan inovasi yang dibawa oleh Yayasan TRAMPIL Indonesia sebagai 
suatu "kabar baik". Disini mereka meyakinkan para guru tersebut bahwa mereka membutuhkan inovasi ini tidak hanya agar mereka dapat terus mengajar, namun juga demi anak-anak didiknya. Jika semua guru di daerah tersebut - yang memang hampir seluruhnya tidak memiliki ijazah S1 - tidak boleh lagi mengajar, maka anak-anak tidak dapat mengenyam pendidikan. Artinya tidak akan ada masa depan bagi wilayah mereka juga. Selain itu para fasilitator juga meyakinkan bahwa program ini tidak akan membebani mereka secara pembiayaan karena akan ada bantuan beasiswa bagi mereka yang tidak mampu. Berkat bantuan dari pemimpin dan fasilitator tersebut program ini dapat diterima dengan baik oleh masyarakat dan saat ini sudah ada lebih dari 1000 orang guru yang dibantu oleh program Learn and Teach.

\section{KESIMPULAN}

Pada tahun 2010, Yayasan TRAMPIL Indonesia melakukan difusi inovasi ke berbagai daerah di Indonesia, terutama yang masih mengalami keterlambatan pembangunan. Difusi inovasi ini bertujuan untuk membantu guru-guru PAUD dan SD agar dapat memperoleh ijazah S1 PGPAUD atau S1 PGSD, sehingga mereka dapat memenuhi standarisasi dari pemerintah. Bentuk inovasinya adalah pembelajaran jarak jauh (e-learning) dengan menggunakan teknologi informasi dan komunikasi, dimana metode pembelajarannya menggunakan blended learning yang menggabungkan pertemuan tatap muka tradisional, web conference, dan learning management system. Saluran komunikasi yang digunakan disini utamanya adalah komunikasi interpersonal dengan komunikator adalah para pejabat struktural dari Yayasan TRAMPIL Indonesia. Waktu untuk difusi inovasi berlangsung adalah 3 tahun, dimana pengambilan keputusan penerima inovasi termasuk cepat dengan hampir tidak adanya penolakan. Sistem sosial yang dimasuki adalah melalui institusi pendidikan atau keagamaan yang dekat dan memiliki pengaruh kuat bagi para guru di daerah tersebut. Pemimpin institusi dan fasilitator memberikan kontribusi yang besar dalam difusi inovasi ini sehingga dapat diterima dengan baik oleh masyarakat.

Keberhasilan dari difusi inovasi ini merupakan kekhasan dari penlitian ini karena teknologi yang dibawa oleh TRAMPIL tergolong cukup mutakhir.
Teknologi tersebut bahkan belum banyak digunakan di kota besar, namun berhasil didifusikan kepada masyarakat di daerah yang belum banyak disentuh oleh pembangunan. Keberhasilan ini ditunjang oleh beberapa hal antara lain momentum yang tepat, relevansi yang tinggi dari inovasi terhadap kebutuhan penerima, saluran komunikasi serta komunikator yang tepat, dan dukungan yang kuat dari sistem sosial. Kesatuan dari unsur-unsur tersebut membuat difusi inovasi menjadi lebih mudah dijalankan dan hasil dari inovasi dapat diterima dengan baik oleh sasaran.

\section{DAFTAR PUSTAKA}

Anderson, T. (2008). The Theory and Practice of Online Learning. Edmonton: AU Press.

Andriono, T. (2015, Juni 3). Sejarah Yayasan TRAMPIL Indonesia. (M. Teguh, Interviewer)

Daymon, C., \& Holloway, I. (2002). Metode-Metode Riset Kualitatif dalam Public Relations dan Marketing Communications. Yogyakarta: Penerbit Bentang.

Hartono. (2007). Geografi: Jelajah Bumi dan Alam Semesta. Bandung: Citra Praya.

Horton, W. (2011). E-Learning by Design (Second Edition). San Fransisco: Pfeiffer.

Hulsmann, M., \& Pfeffermann, N. (2011). Strategies and Communications for Innovations. London: Springer Heidelberg Dordrecht.

Morone, P., \& Taylor, R. (2010). Knowledge Diffusion and Innovation, Modelling Complex Entrepreneurial Behaviours. Cheltenham: Edwar Elgar Publishing Limited.

Paonganan, Y., Zulkipli, R., \& Agustina, K. (2012). 9 Perspektif Menuju Masa Depan Maritim Indonesia. Jakarta: Yayasan Institut Maritim Indonesia.

Pawito. (2007). Penelitian Komunikasi Kualitatif. Yogyakarta: LKiS Yogyakarta.

Raco, J. (2010). Metode Penelitian Kualitatif Jenis, Karakteristik dan Keunggulannya. Jakarta: PT Gramedia Widiasarana Indonesia.

Rogers, E. M. (2003). Diffusion of Innovations. New York: The Free Press.

Rosenberg, M. J. (2001). E-Learning Strategies for Delivering Knowledge in The Digital Age. New York: The McGraw-Hill Companies, Inc.

Sumardi, I. S. (2005). Melawan Stigma Melalui Pendidikan Alternatif. Jakarta: Grasindo. 